\title{
Beras Sebagai Barang Subtitusi dan Komoditi Pangan Utama Jurnal Ecces
}

\author{
William G. M. Louhenapessy ${ }^{1}$ \\ ${ }^{1}$ Program Studi Ilmu Ekonomi \\ Fakultas Keguruan dan Ilmu Pendidikan \\ Jln. Ir. M. Putuhena Kampus Poka, Ambon, Maluku 97233 \\ Telp / Fax : 0911-322626, Universitas Pattimura \\ E-mail : willy_louhenapessy@yahoo.co.uk ${ }^{1}$
}

\section{Abstrak: Beras Sebagai Barang Subtitusi dan Komoditi Pangan Utama}

Terjadinya pertambahan jumlah penduduk yang tidak seimbang dengan pertumbuhan produksi pangan, dimana bahan makanan akan bertambah sesuai deret hitung dan penduduk akan bertambah sesuai deret ukur, mengakibatkan langkanya bahan makanan. Disaat yang sama, tingkat permintaan terhadap pangan semakin meningkat dari waktu ke waktu. Masalah ini, menjadi hal yang cukup serius di Provinsi Maluku. Penelitian ini bertujuan untuk menganalisis hubungan secara parsial antara variabel harga beras dengan variabel ketersediaan pangan rumah tangga di Provinsi Maluku. Penelitian ini dilaksanakan di Provinsi Maluku dengan jumlah sampel sebesar 173 orang. Data yang digunakan pada penelitian ini adalah data primer dengan menggunakan kuesioner dan wawancara langsung dengan responden dan menggunakan data sekunder berupa dari SUSENAS dalam rentang periode waktu penelitian dari tahun 1995 sampai dengan tahun 2014. Analisis yang digunakan untuk menguji hipotesis adalah analisis regresi dengan menggunakan aplikasi SPSS. Hasil penelitian menunjukkan bahwa variabel harga beras berpengaruh signifikan terhadap variabel ketersediaan pangan rumah tangga di Provinsi Maluku. Hasil penelitian ini juga menunjukkan pengaruh yang sangat besar antara harga beras terhadap variabel ketersediaan pangan rumah tangga yaitu sebesar $82,4 \%$.

Kata Kunci: Harga Beras, Ketersediaan Pangan, Maluku.

\section{Abstract:Rice As Substitution Goods and Most Food Commodities}

The occurrence of uneven population increase with the growth of food production, where the food will increase according to arithmetic and the population will increase according to the measuring series, resulting in the scarcity of foodstuffs. At the same time, the level of demand for food is increasing from time to time. This problem is becoming quite serious in Maluku Province. This study aims to analyze the partial relationship between rice price variables and household food availability variable in Maluku Province. This study was conducted in Maluku Province with a total sample of 173 people. The data used in this study is primary data by using questionnaires and direct interviews with respondents and using 
William G. M. Louhenapessy, Beras Sebagai Barang Subtitusi dan Komoditi Pangan Utama.

secondary data in the form of SUSENAS in the period of research period from 1995 to 2014. The analysis used to test the hypothesis is regression analysis using SPSS application . The results showed that rice price variable significantly influenced household food availability variable in Maluku Province. The results of this study also showed a very large influence between the price of rice to household food availability variable of $82.4 \%$.

Keywords: Rice Price, Food Availability, Maluku.

\section{PENDAHULUAN / INTRODUCTION}

Pangan adalah salah satu kebutuhan dasar masyarakat yang harus tetap terpenuhi sehingga merupakan hak dasar yang harus dimiliki bagi seluruh masyarakat untuk mendapatkan pangan. Banyaknya penduduk dan kualitas hidup masyarakat mengakibatkan permintaan akan bahan pangan akan terus meningkat. Robert Maltus (Hafsah, 2006) mengatakan bahwa bertambahnya jumlah penduduk yang tidak seimbang dengan pertumbuhan pangan dunia, dimana bahan makanan akan bertambah sesuai deret hitung dan penduduk akan bertambah sesuai deret ukur, ini mengakibatkan langkanya bahan makanan dunia. Oleh sebab itu, maka pangan menjadi salah satu prioritas utama dalam pembangunan nasional. Istilah pangan dimulai sejak konferensi pangan dunia pada tahun 1971 sampai dekade tahun 90-an mengalami perubahan dari tingkat global, nasional, rumah tangga dan individu yang dilihat dari perspektif pangan sebagai kebutuhan dasar (food first perspective) hingga pada perspektif penghidupan (livelihood perspective) dan indikator objektif ke persepsi subjektif (Maxwell dan Frankenberger, 1992).

Indonesia merupakan salah satu negara yang mempunyai komitmen tinggi terhadap pembangunan ketahanan pangan sesuai amanat UUD 1945 pasal 27. Pertimbangan terhadap komitmen tersebut mendasari lahirnya Undang-Undang Nomor 7/1996, tentang Pangan yang mengamanatkan agar pemerintah bersama masyarakat mewujudkan ketahanan pangan bagi seluruh rakyat Indonesia. Menurut undang-undang tersebut, ketahanan pangan adalah kondisi terpenuhinya kebutuhan pangan bagi rumah tangga yang tercermin dari tersedianya pangan secara cukup, baik dalam jumlah maupun mutunya, aman, merata, dan terjangkau. Menurut Alimoeso (2009), setiap provinsi beserta kabupatennya hendaknya mampu menjabarkan skenario rencana aksi peningkatan produksi dan produktivitas komoditas tanaman pangan.

Di Indonesia, pangan sangat identik dengan beras karena jenis pangan ini merupakan makanan pokok utama. Berdasarkan penelusuran penulis, data menunjukkan bahwa beras telah menjadi bahan pangan pokok bagi lebih dari 95 persen penduduk di Indonesia. Kondisi tersebut menyebabkan pola konsumsi mereka sangat didominasi oleh 
komoditas beras. Oleh karena itu, pemerintah selalu berupaya untuk meningkatkan ketersediaan pangan terutama untuk komoditi beras. Hal tersebut terlihat dari kebijakan pemerintah yang terkait dengan pangan masih terfokus pada komoditas beras. Selain itu, pemerintah juga selalu melakukan untuk melakukan pengawasan ketat terhadap ketersediaan komoditas beras dan bahkan tidak segan untuk melakukan impor beras.

Ketersediaan pangan yang cukup untuk seluruh penduduk di suatu wilayah belum menjamin terhindarnya penduduk dari masalah pangan dan gizi. Kebutuhan pangan untuk konsumsi rumah tangga merupakan hal pokok dalam kelangsungan hidup. Untuk itu, selain ketersediaannya juga perlu diperhatikan pola konsumsi rumah tangga atau keseimbangan kontribusi diantara jenis pangan yang dikonsumsi, sehingga dapat memenuhi standar gizi yang dianjurkan. Dengan demikian, diharapkan bahwa upaya ketahanan pangan keluarga berbasis kearifan lokal di daerah akan memperkaya komoditas pangan di Indonesia, sekaligus turut mendorong kemandirian pangan pada tingkat lokal maupun nasional pada masa akan datang. Hal ini kurang didukung oleh kebijakan pemerintah di daerah masing-masing padahal menurut Tambunan (2008), kurang lebih 60\% penduduk Indonesia yang hidupnya di pedesaan, kebutuhan pangannya bersumber dari pangan lokal.

Kebijakan pelaksanaan ketahanan pangan dengan memanfaatkan pangan lokal merupakan suatu langkah yang tepat, karena ketersediaan pangan lokal disetiap daerah dan sangat mudah untuk dikembangkan, Nainggolan (2004). Sebagai contoh, masyarakat Papua dan Maluku dapat mengkonsumsi ubi jalar sebagai makanan pokok pengganti beras. Di Nusa Tenggara Timur dan Sulawesi Utara sebagai penghasil utama tanaman jagung dapat mengkonsumsi jagung sebahai bahan makanan pokok pengganti beras. Komoditas lain yang berpeluang sangat besar sebagai pengganti beras sebagai bahan makanan pokok adalah sagu yang banyak tersedia di wilayah Indonesia Timur dan Pulau Sumatera.

Ketersediaan pangan rumah tangga difokuskan oleh kemampuan rumah tangga pada pengendalian kebutuhan pangannya. Kemampuan pengendalian tersebut dipengaruhi pada kemampuan rumah tangga untuk memproduksi sendiri bahan pangan serta kemampuan membeli pangan di pasar. Maka, kemampuan membeli pangan inilah yang menjadi sumber ketahanan pangan rumah tangga, yang lebih tergantung pada daya beli rumah tangga (Pakpahan, dkk., 1993). Untuk mencapai ketahanan pangan diperlukan ketersediaan pangan dalam jumlah dan kualitas yang cukup, terdistribusi dengan harga terjangkau dan aman dikonsumsikan bagi setiap warga untuk menopang aktivitasnya sehari-hari sepanjang waktu (Saliem et al., 2002). 
William G. M. Louhenapessy, Beras Sebagai Barang Subtitusi dan Komoditi Pangan Utama.

Ketersediaan pangan rumah tangga masyarakat merupakan rata-rata pangan dalam jumlah yang memenuhi kebutuhan konsumsi ditingkat wilayah dan rumah tangga. Ketersediaan pangan pokok yang cukup ditingkat wilayah tidak menjamin ketersediaan pangan pada tingkat rumah tangga (Kurnia, dkk., 2008). Dari menu makanan yang lebih berat pada makanan pokok dapat diartikan bahwa orientasi kebutuhan pangan bagi rumah tangga pedesaan masih pada tujuan primer, yaitu kuantitas pangan yang banyak agar perut kenyang. Pangan yang dikonsumsikan adalah yang mampu menghasilkan energi yang besar untuk melakukan aktifitas. Kebutuhan yang pokok akan energi dari pangan kiranya sejalan dengan mata pencaharian utama mayoritas rumah tangga pedesaan yang lebih banyak membutuhkan tenaga (otot) dari pada pikiran (otak) (Hanafie, 2010).

Pola konsumsi masyarakat pada masing-masing daerah berbeda-beda, tergantung dari potensi daerah dan struktur budaya masyarakat. Pola konsumsi masyarakat Indonesia masih didominasi oleh padi-padian, khususnya beras, yang diindikasikan oleh tingginya strarchy staple ratio. Masyarakat umumnya mempunyai ketergantungan yang kuat terhadap beras sebagai sumber karbohidrat dan sebagai upaya untuk mengurangi ketergantungan masyarakat pada beras maka perlu menggali potensi lokal yang berbasis non beras untuk memenuhi kebutuhan pangannya (Ni Made Suyastiri Y. P., 2008).

Harga makanan adalah titik penting bagi rumah tangga ketika memutuskan jenis makanan untuk dikonsumsi. Dalam hal ini, sebagian besar penduduk pedesaan mengkonsumsi beras karena harganya disubsidi oleh pemerintah pusat. Harga normal beras baik di pasar sekitar Rp 10.000 per kg (USD 1 per kg), tapi pemerintah pusat mensubsidi harga beras hingga 80 persen sehingga biaya untuk rumah tangga adalah sekitar Rp 2.000 per kg. Bahkan, subsidi beras dialokasikan oleh para perangkat desa untuk semua rumah tangga dipedesaan dan telah gagal untuk mengatasi kelompok sasaran rumah tangga miskin. Oleh karena itu, setiap rumah tangga menerima sekitar $5 \mathrm{~kg}$ per bulan. Jumlah beras ini dianggap terlalu kecil untuk memenuhi kebutuhan gizi empat anggota rumah tangga, meskipun konsumsi beras telah mengubah pola kebiasaan makanan lokal dengan beras menjadi makanan yang disukai karena harga pasarnya (Girsang, 2014). Di Maluku, meskipun harga beras cenderung meningkat dalam dekade terakhir, tampaknya bahwa orang lebih memilih untuk membeli dan mengkonsumsi beras dari pada sagu dan makanan lokal lainnya. Konsumsi beras juga berpengaruh terhadap makanan lokal yang ditemukan di pulau-pulau kecil di Negara Federasi Mikronesia karena beras lebih lezat dan sederhana untuk disajikan (Yamamoto, 2013). Kecenderungan masyarakat untuk mengkonsumsi beras dari pada memilih pangan lokal yang lebih murah dan tersedia disekitar wilayahnya. 
Provinsi Maluku adalah Provinsi dengan luas daratan lebih sedikit dibandingkan dengan luas lautnya, kondisi ini mengisyaratkan bahwa proses distribusi pangan ke wilayah Maluku sebagian besar dilakukan melalui laut yang tentunya sering mengalami gangguan distribusi terutama pada cuaca ekstrim yang sering terjadi. Oleh karena itu diwilayah ini sering terjadi gejolak harga pangan terutama untuk komoditas pangan yang dipasok dari luar (Dewan Ketahanan Pangan Propinsi Maluku, 2015).

Data pada Dewan Ketahanan Pangan Propinsi Maluku tahun 2015, menunjukkan bahwa harga beras di tingkat pedagang grosir maupun pedagang eceran tidak mengalami kenaikkan harga untuk masing-masing kabupaten/kota. Harga tertinggi pada Kabupaten Maluku Tenggara Barat yakni Rp. 12.000 per kilogram dan harga terendah pada kabupaten Maluku Tenggara, kabupaten Maluku Tengah, kabupaten Seram Bagian Timur, kabupaten Buru, dan Kota Ambon yakni Rp. 8.500 per kilogram sedangkan pada kabupaten Seram Bagian Barat, kabupaten Buru Selatan dan Kepeluan Aru berada pada harga Rp.11.000 per kilogram.

Pada tahun 1980-an, sebanyak 33\% masyarakat di Provinsi Maluku masih menjadikan sagu sebagai bahan makanan pokok, 50\% menggunakan sagu dan umbiumbian dan hanya $17 \%$ menggunakan beras sebagai bahan makanan pokok (Louhenapessy, 2007). Namun, Girsang (2014) menyebutkan bahwa konsumsi sagu dan makanan lokal lainnya di Provinsi Maluku mulai berkurang sementara konsumsi beras telah meningkat secara signifikan dalam dekade terakhir. Beberapa faktor yang mempengaruhi masyarakat Maluku meninggalkan pangan lokanya dan beralih ke beras adalah (a) adanya alih fungsi lahan sagu, umbi-umbian dan jagung menjadi lahan sawah, (b) beras merupakan komoditas bergengsi yang dapat meningkatkan status sosial dan tersedia dalam jumlah yang memadai serta mudah diperoleh, (c) umur panen sagu relatif lebih lama (8-10 tahun), (d) pemerintah daerah belum memperhatikan sagu sebagai pangan lokal, sehingga lahan sagu dikonversi menjadi lahan sawah, (e) lemahnya sosialisasi kebiasaan (tradisi) makan sagu dari generasi ke generasi, (f) tidak tersedianya produk sagu dalam kualitas, kuantitas, waktu dan tempat yang memadai, (g) diversifikasi produk masih terbatas, dan (h) meningkatnya status sosial ekonomi masyarakat semakin membaik, sehingga beralih ke beras (Hetharia, 2006).

Provinsi Maluku terdiri dari 9 Kabupaten dan 2 Kota. Baik Kabupaten maupun Kota merupakan wilayah pertanian sedangkan kota merupakan wilayah industri dengan skala kecil. Perekonomian Provinsi Maluku bertumpu pada sektor pertanian, namun dalam perkembangnnya Provinsi Maluku mengalami pergeseran struktur perekonomian yaitu dari 
William G. M. Louhenapessy, Beras Sebagai Barang Subtitusi dan Komoditi Pangan Utama.

sektor pertanian ke sektor Jasa. Hal inilah yang menyebabkan adanya perbedaan antara pedesaan dan perkotaan. Kondisi tersebut juga menimbulkan adanya pergeseran atau perubahan pola konsumsi pangan penduduk di Provinsi Maluku.

Usaha tani padi di Provinsi Maluku terdiri dari usaha tani padi sawah dan padi ladang. Pada umumnya usaha tani padi sawah dilakukan oleh petani transmigran, sedangkan untuk padi ladang umumnya dilakukan oleh petani lokal. Perkembangan produksi padi secara keseluruhan di Provinsi Maluku disajikan pada tabel berikut. Dari data yang ada, dapat dijelaskan bahwa pada tahun 2010 produksi padi di Maluku sebesar 83.109 ton dan mengalami kenaikan tertinggi pada tahun 2015 sebesar 117.791 ton. Kenaikan jumlah produksi ini disebabkan oleh adanya kebijakan pemerintah Provinsi Maluku untuk meningkatkan produksi padi sebagai salah satu komiditi pangan strategis di Maluku untuk mendukung ketersediaan pangan di Maluku. Karena itu pembukaan lahan sawah di Kabupaten Buru dan Kabupaten Seram Bagian Barat (SBB) merupakan salah satu target pemerintah Provinsi Maluku untuk mendukung penyediaan padi sebagai salah satu produk pangan di Maluku.

Produksi Padi dan Jagung di Maluku Tahun 2010 - 2015 (Ton).

\begin{tabular}{lcccccc}
\hline \multicolumn{1}{c}{ Jenis Pangan } & 2010 & 2011 & 2012 & 2013 & 2014 & 2015 \\
& & & & & & \\
\hline Jagung & 15.273 & 13.875 & 18.281 & 11.940 & 10.568 & 13.947 \\
Padi & 83.109 & 87.468 & 84.271 & 101.835 & 102.761 & 117.791 \\
\hline
\end{tabular}

Sumber: BPS data diolah

Perkembangan hasil produksi padi di Provinsi Maluku menunjukkan kecendrungan yang positif, walaupun pada tahun 2012 produksi padi sedikit mengalami penurunan dari tahun sebelumnya menjadi 84.271 ton. Namun, jika dilihat dari produktivitasnya semakin meningkat. Data tersebut menunjukkan bahwa produksi padi baik padi sawah maupun padi ladang terbesar dihasilkan oleh Kabupaten Seram Bagian Barat dan Kabupaten Buru. Penurunan produksi padi tahun 2012 terjadi karena adanya penurunan luas panen dan juga disebabkan oleh penurunan produksi padi lading. Pada tahun 2013 produksi padi mengalami peningkatan kembali sebesar 102.761 ton lebih besar dari tahun sebelumnya yaitu 84.271 ton atau naik sebesar 17.564 ton. Pada tahun 2014 jumlah produksi padi terus mengalami kenaikan sebesar 102.761 ton sedik lebih besar dari tahun sebelumnya, atau mengalami perubahan kenaiakn sebesar 926 ton, dimana tingkat perubahan kenaikan ini lebih rendah dari perubahan kenaikan dari tahun 2012 ke 2013. Pada tahun 2015 kenaikan hasil produksi padi di Maluku sangat besar yaitu 117.791 ton atau naik 15.030 ton lebih besar dari 
kenaikan tahun-tahun sebelumnya. Diduga bertambahnya luas lahan sawah dan meningkatnya luas panen menyebabkan rata-rata produktivitas padi meningkat lebih besar dibandingkan dengan tahun-tahun sebelumnya. Hal menarik untuk ditelusuri lebih lanjut apakah harga beras berpengaruh terhadap ketersediaan pangan rumah tangga di Provinsi Maluku?. Oleh karena itu, tujuan yang akan dicapai melalui penelitian ini adalah menganalisis hubungan secara parsial antara variabel harga beras dengan variabel ketersediaan pangan rumah tangga di Provinsi Maluku. Hal ini menjadi cukup penting karena sampai saat ini, masih terdapat inkonsistensi baik secara teoritik dan empirik mengenai hubungan kausalitas antara harga beras, dengan variabel ketersediaan pangan rumah tangga.

\section{TINJAUAN TEORITIK / LITERATURE REVIEW}

\section{Teori Permintaan}

Teori permintaan konsumen, didasarkan pada teori perilaku konsumen (consumer behavior). Perilaku konsumen adalah tindakan yang langsung terlibat dalam mendapatkan, mengkonsumsi dan menghabiskan produk dan jasa, termasuk proses keputusan yang mendahului dan menyusuli tindakan ini (Engel, dkk., 1993). Jumlah barang yang diminta sangat dipengaruhi oleh harga barang tersebut. Semakin tinggi harga barang, maka permintaan terhadap barang tersebut akan menurun, begitu juga sebaliknya. Selain harga barang itu sendiri, harga barang lain yang terkait pun ikut berpengaruh terhadap permintaan konsumen. Hal ini yang disebut dengan hubungan subtitusi dan komplementer. Pada hubungan subtitusi, bila terjadi kenaikan harga pada salah satu barang akan memicu kenaikan jumlah permintaan barang lain.

Pada dasarnya teori permintaan mendiskripsikan bagaimana seorang konsumen mengkonsumsi sejumlah barang tertentu pada tingkat harga tertentu. Jika tingkat harga tinggi, maka jumlah barang yang dikonsumsi akan turun, sebaliknya jika tingkat harga rendah, maka jumlah barang yang dikonsumsi akan naik (cateris paribus). Dalam proses konsumsi menggunakan pendapatan yang ia dapat dari proses produksi. Persoalannya adalah bagaimana seorang konsumen mengalokasi pendapatannya untuk memperoleh sejumlah barang tertentu agar konsumen tersebut dapat mencapai kepuasan maksimum (maximization satisfaction). Ini adalah tujuan utama seorang konsumen dalam proses konsumsi untuk mencapai kepuasan yang maksimum. 
William G. M. Louhenapessy, Beras Sebagai Barang Subtitusi dan Komoditi Pangan Utama.

Dalam membicarakan teori perilaku konsumen ada tiga pendekatan yang dipakai yaitu pertama, pendekatan kardinal (cardinal approach), yaitu suatu pendekatan yang mengatakan bahwa tingkat kepuasan konsumen itu dapat diukur atau dapat dikuantifikasi dengan angka-angka kardinal, kedua, pendekatan ordinal (ordinal approach), yaitu suatu pendekatan yang mengatakan bahwa kepuasan konsumen dalam proses konsumsi tidak dapat diukur, tetapi dapat diperbandingkan menurut rangking-rangking kepuasan, dan ketiga, pendekatan atribut (attribute approach), yaitu pendekatan yang mengatakan bahwa kepuasan konsumen dalam mengkonsumsi barang dan jasa ditentukan oleh atribut yang melekat pada barang yang dikonsumsi tersebut (Latumaerissa, 2003). Dalam menjelaskan preferensi konsumen dalam proses konsumsi maka kita kenal dengan kurva indeferensi (indefernce curve). Yang dimaksudkan dengan kurva indiferensi adalah suatu kurva yang menjelaskan tentang kombinasi dua jenis barang atau lebih tetapi dapat memberikan kepuasan yang sama kepada konsumen.

\section{Pangan dan Pertumbuhan Penduduk}

Berdasarkan pandangan teori klasik Malthus dalam Subejo (2009), mengemukakan bahwa jumlah penduduk senantiasa bertambah banyak sedangkan pertumbuhan produksi tidaklah banyak sehingga salah satu solusi terbaik adanya pengendalian jumlah penduduk. Malthus khawatir terhadap dampak pertumbuhan penduduk terhadap pertumbuhan ekonomi walaupun sebenarnya bisa menjadi asumsi bahwa pertambahan penduduk bisa memicu proses industrialisasi. Thomas R. Malthus dalam teorinya mengatakan bahwa pertumbuhan penduduk mengikuti deret ukur sedangkan pertumbuhan ketersediaan pangan mengikuti deret hitung. Thomas Robert Malthus melontarkan kerisauannya apakah produksi pertanian dunia mampu memenuhi permintaan pangan penduduk? Pada 1798 Thomas Robert Malthus menulis buku "Essay on the Principle of Population" yang menganalisis tendensi universal penduduk suatu negara untuk berkembang secara deret ukur (geometris) dengan berlipatdua setiap 30 sampai 40 tahun, kecuali jika dicegah dengan mengecilnya bahan makanan. Pada waktu yang sama karena menurunnya kenaikan hasil (diminishing return) atas faktor produksi tetap yaitu tanah, bahan makan hanya akan bertambah secara deret hitung (aritmatis). Bahkan, karena setiap anggota penduduk mengerjakan tanah yang semakin sempit, maka kontribusi marjinalnya terhadap produksi makanan menurun. Malthus memberika kesimpulan dan solusinya dengan dua hal utama, pertama pembukaan tanah lebih banyak dan dengan menganjurkan pertanian sebesarbesarnya, kemudian jika cara ini dipandang masih belum efektif dalam mengatasi kerawanan pangan, maka yang kedua adalah dengan pengendalian pertumbuhan penduduk. Pengendalian inilah yang sering 
disebut Malthus dengan "pengendalian langsung" yang ditujukan kepada "golongan positif" seperti pekerjaanpekerjaan yang yang tak sehat, kerja yang berat, kemelaratan yang teramat sangat, penyakit, perawatan anak-anak yang tak baik, kota-kota besar, pes, epidemi; serta "golongan preventif", yaitu pengekangan moral dan adanya cacat jasmani.

Namun pandangan tersebut ditentang oleh Karl Marx dalam Subejo (2009) bahwa tekanan penduduk disuatu negara bukanlah tekanan terhadap bahan makanan, akan tetapi tekanan terhadap kesempatan kerja (seperti yang terjadi di negara-negara kapitalis). Marx juga berpendapat bahwa semakin banyak jumlah manusia, semakin tinggi jumlah produk yang dihasilkan, jadi dengan demikian tidak perlu dilakukan pembatasan penduduk. Karl Marx merupakan salah satu penentang teori Malthus, prinsip yang terbangun dalam pemikiran Marx adalah tidak ada aturan yang bersifat umum untuk kependudukan (Population Laws). Menurut dia, kondisi penduduk sangat tergantung pada kondisi sosial dan ekonomi suatu daerah. Perbedaan fertilitas dan mortalitas ditentukan oleh variasi tingkat kehidupan, perbedaan ini akan hilang, apabila kekayaan didistribusikan secara merata kepada masyarakat. Ketidaksetujuannya terhadap teori Malthus adalah tentang pertumbuhan bahan makanan, Marx mengatakan bahwa ide tersebut tidak benar, selama tidak ada alasan untuk curiga bahwa sains dan teknologi mampu meningkatkan produksi bahan makanan atau barang-barang lainnya sama seperti pertumbuhan penduduk.

Akan tetapi Kuznets mencoba meluruskan hal tersebut bahwa (1964), pertanian di LDCs dapat dilihat sebagai suatu sektor ekonomi yang sangat potensial dalam empat bentuk kontribusinya terhadap pertumbuhan dan pembangunan ekonomi nasional, yaitu sebagai berikut. Pertama, ekspansi dari sektor-sektor ekonomi lainnya sangat tergantung pada pertumbuhan output di sektor pertanian, baik dari sisi permintaan sebagai sumber pemasokan makanan yang kontinyu mengikuti pertumbuhan penduduk, maupun dari sisi penawaran sebagai sumber bahan baku bagi keperluan produksi di sektor-sektor lain seperti industri manufaktur (misalnya industri makanan dan minuman) dan perdagangan. Kuznets menyebutnya kontribusi pasar. Kedua, di negara-negara agraris seperti indonesia, pertanian berperan sebagai sumber penting bagi pertumbuhan permintaan domestik bagi produkproduk dari sektor-sektor ekonomi lainnya. Kuznets menyebutnya kontribusi pasar. Ketiga, sebagai suatu sumber modal untuk investasi di sektor-sektor ekonomi lainnya. Selain itu, menurut teori penawaran tenaga kerja $(\mathrm{L})$ tak terbatas dari Arthur Lewis dan telah terbukti dalam banyak kasus, bahwa dalam proses pembangunan ekonomi terjadi transfer surplus $\mathrm{L}$ dari pertanian (pedesaan) ke industri dan sektor-sektor perkotann lainnya. Kuznets menyebutnya kontribusi faktor-faktor produksi.Keempat, sebagai sumber penting bagi 
William G. M. Louhenapessy, Beras Sebagai Barang Subtitusi dan Komoditi Pangan Utama.

surplus neraca perdagangan (sumber devisa), baik lewat ekspor hasil-hasil pertanian maupun dengan peningkatan produksi pertanian dalam negeri menggantikan impor (subsitusi impor). Kuznets menyebutnya kontribusi devisa.

\section{Kontribusi Produk}

Konstribusi pertanian terhadap PDB dapat dilihat dari relasi antara pertumbuhan dari kontribusi tersebut dengan pangsa PDB awal dari pertanian dan laju pertumbuhan relatif dari produk-produk neto pertanian dan non pertanian. Jika $\mathrm{Pp}=$ produk neto pertanian, Pnp $=$ produk neto non pertanian, dan $\mathrm{Pn}=$ total produk nasional atau PDB.

Laju penurunan peran sektor pertanian secara relatif di dalam ekonomi cenderung berasosiasi dengan kombinasi dari tiga hal berikut. Pangsa PDB awal dari sektor-sektor non pertanian yang relatif lebih tinggi daripada pangsa PDB awal dari pertanian, laju pertumbuhan output pertumbuhan yang relatif rendah, dan laju pertumbuhan output dari sektor-sektor non pertanian yang relatif tinggi (yang membuat suatu perbedaan positif yang besar antara pangsa PDB dari nonpertanian dengan pangsa PDB dari pertanian.

Di dalam sistem ekonomi terbuka, besarnya kontribusi produk terhadap PDB dari sektor pertanian baik lewat pasar maupun lewat keterkaitan produksi dengan sektor-sektor non pertanian, misalnya industri manufaktur, juga sangat dipengaruhi oleh kesiapan sektor itu sendiri dalam menghadapi persaingan dari luar. Dari sisi pasar, kasus Indonesia menunjukkan bahwa pasar domestik didominasi oleh berbagai produk pertanian dari luar negeri, mulai dari beras, buah-buahan, sayuran, hingga daging. Dari sisi keterkaitan produksi, kasus Indonesia menunjukkan bahwa banyak industri seperti industri minyak kelapa sawit (CPO) mendapatkan bahan baku di dalam negeri karena komoditi-komoditi tersebut di ekspor dengan harga jual di pasar luar negeri jauh lebih mahal daripada di jual ke industri-industri tersebut.

2. Kontribusi Produk

Negara agraris dengan proporsi populasi pertanian (petani dan keluarganya) yang besar seperti Indonesia merupakan sumber sangat penting bagi pertumbuhan pasar domestik produk-produk dari sektor nonpertanian, khususnya industri manufaktur. Pengeluaran petani untuk produk-produk industri, baik barang-barang konsumer (makanan,pakaian,rumah atau bahan-bahan bangunan, transportasi, mebel dan peralatan rumah tangga lainnya), maupun barang-barang perantara untuk kegiatan produksi (pupuk, pestisida, alat-alat pertanian).

Dua faktor penting yang dapat sebagai prasyarat peranan sektor pertanian lewat kontribusi pasarnya terhadap diversifikasi dan pertumbuhan output sektor-sektor non 
pertanian. Pertama, dampak dari ketrebukaan ekonomi dimana pasar domestik tidak hanya diisi oleh barang-barang buatan dalam negeri, tetapi juga barang-barang impor. Kedua, jenis teknologi yang digunakan di sektor pertanian yang menentukan tinggi rendahnya tingkat mekanisasi atau modernisasi di sektor tersebut.

\section{Kontribusi Faktor-Faktor Produksi}

Ada dua faktor produksi yang dapaat di alihkan dari pertanian ke sektor-sektor nonpertanian, tanpa harus mengurangi volume produksi(produktivitas) di sektor pertama. Pertama, L: di dalam teori Arthur Lewis dikatakan bahwa pada saat pertanian mengalami surplus $L$ (dimana MP dari penambahan satu $L$ mendekati atau sama dengan nol) yang menyebabkan tingkat produktivitas dan pendapatan riil per $\mathrm{L}$ di sektor tersebut rendah, akan terjadi transfer $\mathrm{L}$ dari pertanian ke industri. Kedua, modal: surplus pasar (MS) di sektor pertanian bisa menjadi salah satu sumber I di sektor-sektor lain. MS adalah surplus produk (Pp) dikali harga jual (Pp).

$$
\mathrm{MS}=\mathrm{Pp} \times \mathrm{Pp}
$$

Selain faktor-faktor di atas, untuk mendapatka MS, kinerja sektor pertanian itu sendiri harus baik, dalam arti bisa menghasilkan surplus, dan terakhir ini sangat ditentukan oleh kekuatan sisi suplainya (teknologi, infrastruktur dan SDM), serta dari sisi permintaan (pasar) oleh nilai tukar antara produk pertanian dengan produk nonpertanian, baik di pasar dalam negeri maupun luar negeri.

4. Kontribusi Devisa

kontribusi sektor pertanian terhadap peningkatan devisa adalah lewat peningkatan ekspor ( $x$ ) dan/atau pengurangan tingkat ketergantungan negara tersebut dengan impor (M) atas komoditi-komoditi pertanian. Tentu, kontribusi sektor itu terhadap $\mathrm{X}$ juga bisa bersifat tidak langsung, misalnya lewat peningkatan $X$ atau pengurangan $M$ produk-produk berbasis pertanian seperti makanan dan minuman, tekstil dan produk-produknya, barangbarang dari kulit, ban mobil, obat-obatan, dan lain-lain.

Akan tetapi, peran sektor pertanian dalam peningkatan devisa bisa kontradiksi dengan perannya dalam bentuk kontribusi produk. Seperti telah dibahas sebelumnya, kontribusi produk dari sektor pertanian terhadap pasar dan industri domestik bisa tidak besar karena sebagaian besar produk pertanian di ekspor dan/atau sebagaian besar kebutuhan pasar dan industri domestik di suplai oleh produk-produk impor. Dalam kata lain, usaha peningkatan $\mathrm{X}$ pertanian bisa berakibat negatif terhadap pasokan pasar dalam negeri, atau sebaliknya, usaha memenuhi kebutuhan pasar dalam negeri bisa menjadi suatu faktor penghambat bagi pertumbuhan $\mathrm{X}$ pertanian. 
William G. M. Louhenapessy, Beras Sebagai Barang Subtitusi dan Komoditi Pangan Utama.

Untuk menghindari trade-off seperti ini, maka ada dua hal yang perlu dilakukan di sektor pertanian, yakni menambah kapasitas produksi di satu sisi, dan meningkatkan daya saing produk-produknya di sisi lain. Namun, bagi banyak LDCs termasuk Indonesia, melaksanakan duapekerjaan ini tidak mudah, terutama karena keterbatasan teknologi, SDM, dan $\mathrm{K}$.

\section{METODE PENELITIAN / METHODS}

Penelitian ini dilakukan untuk menjelaskan hubungan antara variabel harga beras (X1) terhadap ketersediaan pangan rumah tangga (Y1) di Provinsi Maluku. Harga Beras adalah nilai moneter dari satu kilogram beras yang dapat dikonsumsi oleh rumah tangga untuk memenuhi kebutuhan konsumsi rata-rata tiga bulan terakhir dan dihitung dalam rupiah $(\mathrm{Rp})$ per kilogram $(\mathrm{kg})$. Ketersediaan pangan rumah tangga adalah cadangan pangan yang dimiliki oleh rumah tangga dalam satu bulan yang dikeluarkan oleh satu rumah tangga untuk memenuhi kebutuhan akan konsumsi pangan dan diukur dengan satuan rupiah (Rp).

Penelitian dilaksanakan di Provinsi Maluku dengan jumlah sampel keseluruhan 173 orang responden. Jenis data yang digunakan dalam penelitian ini adalah data primer data yang diperoleh melalui penelitian langsung pada obyek penelitian dan data sekunder yang diperoleh dari SUSENAS dalam rentang periode waktu penelitian dari tahun 1995 sampai dengan tahun 2014. Data yang terkumpul akan dianalisis dengan menggunakan metode analisis regresi sederhana dengan menggunakan bantuan aplikasi SPPS. Adapun kerangka konseptual dan hipotesis penelitian adalah sebagai berikut :

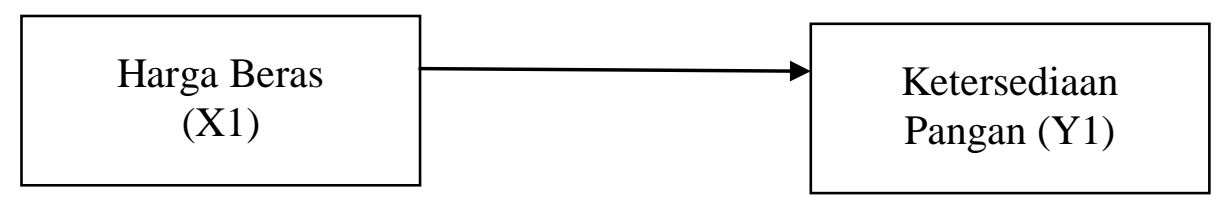

Berdasarkan gambar diatas, hipotesis penelitian adalah harga beras berpengaruh terhadap ketersediaan pangan.

\section{HASIL DAN PEMBAHASAN / DISCUSSION}

Pengujian Normalitas

Uji normalitas adalah uji statistik yang dilakukan untuk mengetahui sebaran data penelitian. Pada penelitian ini, uji normalitas dilakukan dengan metode Uji Normalitas 
Kolmogorov - Smirnov Test. Uji Kolmogorov - Smirnov Test merupakan salah satu pengujian normalitas yang sering digunakan dimana kelebihannya adalah tidak menimbulkan perbedaan persepsi diantara satu pengamat dengan pengamat yang lain. Konsep dasar uji ini adalah dengn membandingkan distribusi data (yang akan diuji normalitasnya) dengan distribusi normal baku.

Hasil pengolahan data pada tabel uji normalitas menunjukkan bahwa nilai signifikansi sebesar 0,218, dimana syarat untuk data dikatakan normal adalah jika nilai sig $>0,05$. Hal tersebut menunjukkan bahwa tidak terdapat perbedaan signifikan dengan data normal baku sehingga dapat dikatakan bahwa data tersebut normal.

Adapun hasil pengujian tersebut dapat dilihat pada tabel berikut:

Tabel Hasil Uji Nomalitas

One-Sample Kolmogorov-Smirnov Test

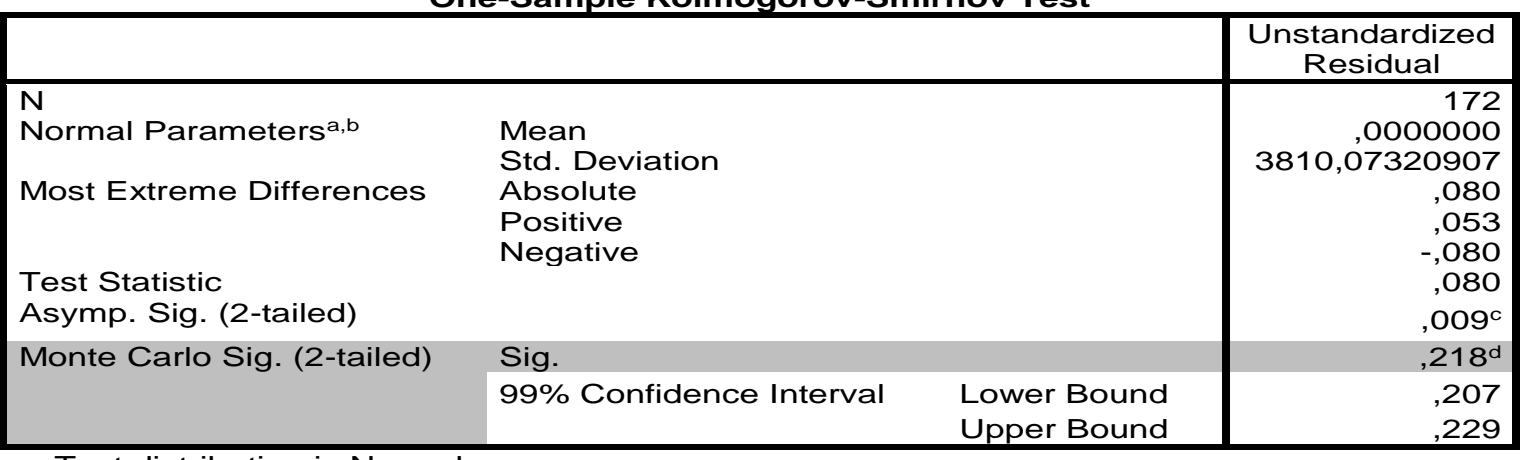

a. Test distribution is Normal.

b. Calculated from data.

c. Lilliefors Significance Correction.

d. Based on 10000 sampled tables with starting seed 743671174 .

Uji Autokorelasi

Uji autokorelasi adalah pengujian yang dilakukan untuk melihat apakah terjadi korelasi antar suatu periode $\mathrm{t}$ dengan periode $\mathrm{t}$ sebelumnya $(\mathrm{t}-1)$. Uji autokorelasi yang digunakan pada penelitian ini adalah Runs Test dan Durbin Watson. Uji Runs Test digunakan untuk menguji apakah antar resudial terdapat korelasi yang tinggi atau tidak. Syarat uji Runs Test adalah nilai signifikansi > 0,05. Selain menggunakan uji Runs Test, penelitian ini juga melihat nilai Durbin-Watson untuk keperluan autokorelasi. Adapun hasil uji runs test dan Durbin Watson dapat dilihat pada Tabel 3 dan tabel 4 sebagai berikut:

Tabel Hasil Uji Autokorelasi (Runs Test)

Runs Test

\begin{tabular}{|c|c|c|c|}
\hline \multicolumn{3}{|c|}{ 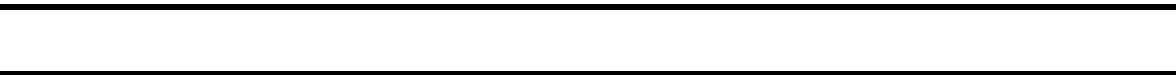 } & $\begin{array}{c}\text { Unstandardized } \\
\text { Residual }\end{array}$ \\
\hline $\begin{array}{l}\text { Test Value } \\
\text { Cases }<\text { Test Value } \\
\text { Cases }>=\text { Test Value } \\
\text { Total Cases } \\
\text { Number of Runs } \\
\text { Z } \\
\text { Asymp. Sig. (2-tailed) } \\
\text { Monte Carlo Sig. (2-tailed) }\end{array}$ & Sig. & & $\begin{array}{r}329,84932 \\
86 \\
86 \\
172 \\
78 \\
-1,377 \\
169 \\
195^{\mathrm{b}}\end{array}$ \\
\hline & $99 \%$ Confidence Interval & $\begin{array}{l}\text { Lower Bound } \\
\text { Upper Bound }\end{array}$ & $\begin{array}{l}, 185 \\
, 205\end{array}$ \\
\hline
\end{tabular}

b. Based on 10000 sampled tables with starting seed 1502173562. 
Tabel Hasil Uji Autokorelasi (Durbin-Watson)

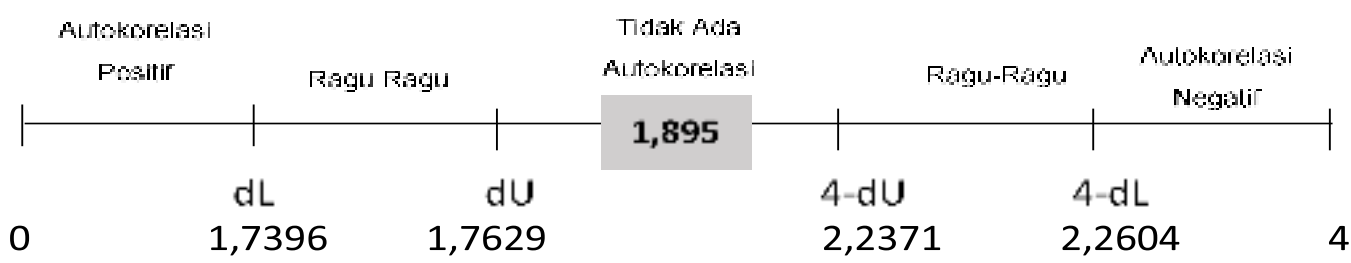

Hasil pengolahan data pada tabel tersebut menunjukkan bahwa nilai signifikansi sebesar 0,185 , dimana syaratnya adalah jika nilai sig $>0,05$. Hal tersebut menunjukkan bahwa data yang digunakan pada penelitian ini cukup random sehingga tidak terdapat masalah autokorelasi pada data yang diuji.

Hasil pengolahan data pada tabel 4 menunjukkan bahwa nilai Durbin-Watson sebesar 1,895, dimana syaratnya adalah jika nilai Durbin-Watson terletak diantara nilai dU dan 4-dU, maka disimpulkan tidak terjadi autokorelasi. Nilai dU, ditentukan berdasarkan jumlah sampel sebesar 172 dan nilai $k=1$, adalah sebesar 1,7622. Sehingga diperoleh hasil 1,7622 <1,895 $<2,2378$ yang kemudian disimpulkan bahwa tidak terdapat masalah autokorelasi pada data yang diuji.

Uji Regresi

Analisis regresi mempelajari bentuk hubungan antara satu atau lebih peubah/variabel bebas (X) dan satu variabel tidak bebas $(\mathrm{Y})$. Pada penelitian ini terdapat satu variabel bebas dan satu variabel tidak bebas, sehingga analisis regresi sederhana sudah cukup untuk menunjukkan pengaruh antara variabel tersebut. Variabel bebas dalam penelitian ini adalah harga beras $(X)$ dan variabel tidak bebas adalah ketersediaan pangan rumah tangga $(Y)$. Hasil analisis regresi dapat dilihat pada tabel berikut:

Tabel Hasil Analisis Regresi

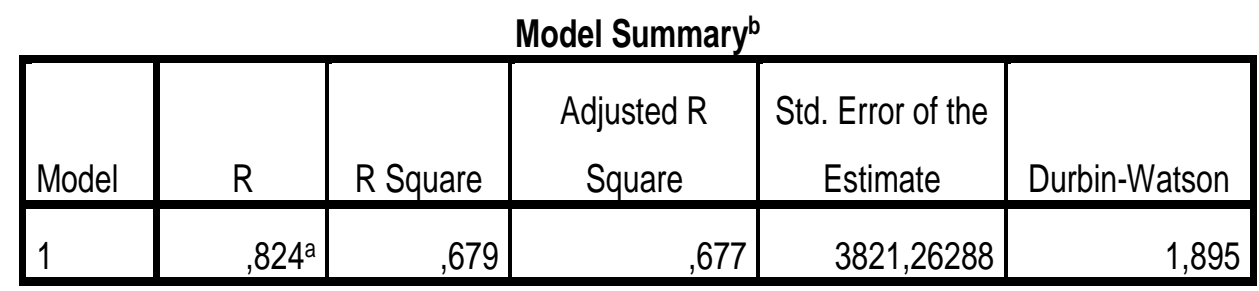
a. Predictors: (Constant), X1
b. Dependent Variable: Y1 
Tabel Hasil Analisis Regresi (ANOVA)

\begin{tabular}{|ll|r|r|r|r|r|}
\hline \multicolumn{2}{|l|}{ ANOVA $^{\mathrm{a}}$} \\
\hline 1 & Sum of Squares & \multicolumn{1}{c|}{ df } & Mean Square & \multicolumn{1}{c|}{ F } & Sig. \\
\hline & Regression & 5242759173,060 & 1 & 5242759173,060 & 359,043 &, $000^{\mathrm{b}}$ \\
& Residual & 2482348493,801 & 170 & 14602049,964 & & \\
& Total & 7725107666,860 & 171 & & & \\
\hline
\end{tabular}

a. Dependent Variable: Y1

b. Predictors: (Constant), $\mathrm{X} 1$

Hasil analisis data pada tabel tersebut menunjukkan bahwa nilai $\mathrm{R}$ dan $\mathrm{R}$ square sebesar 0,824 dan 0,679. Nilai $\mathrm{R}$ sebesar 0,824 menunjukkan bahwa pengaruh variabel harga beras terhadap ketersediaan pangan rumah tangga di Provinsi Maluku sebesar 82,4\%, dimana 17,6\% ketersediaan pangan rumah tangga di Provinsi Maluku dipengaruhi oleh faktor lain. Karena nilai R bisa dikatakan terpengaruh oleh berbagai nilai pengganggu yang mungkin menyebabkan kesalahan pengukuran, untuk itu dapat digunakan nilai alternatif yaitu R Square. Pada tabel dapat dilihat bahwa nilai R square yang berarti bahwa besar pengaruh variabel harga beras terhadap ketersediaan pangan rumah tangga di Provinsi Maluku sebesar 0,679.

Hasil analisis data pada tabel tersebut menunjukkan bahwa nilai sig adalah sebesar 0,00 , dimana jika nilai sig < 0,05 maka dinyatakan bahwa seluruh variabel bebas berpengaruh terhadap variabel tidak bebas. Sehingga, dapat disimpulkan bahwa variabel harga beras berpengaruh signifikan terhadap ketersediaan pangan rumah tangga di Provinsi Maluku.

Pengaruh Harga Beras Terhadap Ketersediaan Pangan

Harga (price) adalah nilai yang melekat pada suatu barang atau produk tertentu yang digunakan sebagai satuan atau alat hitung dalam proses transaksi ekonomi. Berdasarkan pemahaman tersebut maka harga beras dalam penelitian ini didefinisikan sebagai nilai moneter yang melekat pada produk beras yang berfungsi sebagai alat kesatuan hitung dalam proses transaksi. Harga beras merupakan salah satu variabel penting dalam penelitian ini, karena beras adalah salah satu pangan strategis di Maluku selain pangan non beras, karena itu dalam berbagai kajian dan analisis tentang pangan maka beras selalu menjadi bahan penelitian, kajian dan analisis. 


\section{Tabel Alokasi Pendapatan Rumah Tangga Responden Untuk Konsumsi Pangan Beras di Daerah Penelitian Tahun 2017 (Harga per Kg)}

\begin{tabular}{cccc}
\hline No & Harga per Kg & Rumah Tangga Responden & Persentasi \\
\hline 1 & $\leq$ Rp. 10.000 & 55 & 27,5 \\
2 & $\geq$ Rp. 10.000 & 145 & 72,5 \\
\hline
\end{tabular}

Sumber: Data Primer, diolah 2017

Informasi pada tabel-7 jelas menggambarkan kondisi riil di daerah penelitian bahwa rumah tangga responden yang mengkonsumsi pangan beras pada tingkat harga beras/kg $\geq \mathrm{Rp}$. 10.000 sebesar $72,5 \%$ atau 145 rumah tangga lebih besar dari rumah tangga responden yang mengkonsumsi beras pada tingkat harga $\leq$ Rp. 10.000 yang hanya sebesar 27,5\% atau 55 rumah tangga. Hal ini diketahui bahwa persepsi rumah tangga di daerah penelitian lebih cenderung untuk mengkonsumsi beras dengan kualitas yang lebih baik dengan merekmerek tertentu jika dibandingka dengan beras yang harga murah atau lebih rendah. Ini berarti dapat disimpulkan bahwa rumah tangga responden baik yang dipedesaan atau di perkotaan telah memiliki kesadaran terhadap konsumsi jenis pangan beras yang lebih sehat dan berkualitas untuk mempertahan gizi karbohidrat yang mencukupi kebutuhannya. Selain itu alasan rumah tangga di daerah penelitian untuk mengkonsumsi beras dengan kualitas yang lebih baik sekalipun harus membayar harga yang lebih mahal disebabkan daya beli (deman power) rumah tangga responden yang relatif baik sehingga alokasi pendapatan yang dimiliki diarahkan untuk mengkonsumsi pangan beras yang berkualitas.

Selain itu alokasi pendapatan rumah tangga responden untuk mengkonsumsi pangan beras dilihat dari harga per karung ( $25 \mathrm{~kg}$ ) maka diketahui bahwa rumah tangga di daerah penelitian yang mengkonsumsi pangan beras dengan harga per kariung ( $25 \mathrm{~kg}$ ) pada tingkat harga $\geq$ Rp. 250.000 sebesar 108 rumah tangga atau 54\% dari total rumah tangga responden. Sedangkan rumah tangga responden yang mengkonsumsi pangan beras dengan tingkat harga per karung $(25 \mathrm{~kg}) \leq \mathrm{Rp} .250 .000$ hanya sebesar $46 \%$ dari total rumah tangga responden atau sebesar 92 rumah tangga responden. Dari informasi tabel di atas maka disimpulkan bahwa hal ini terjadi karena kesadaran rumah tangga responden dalam kegiatan konsumsi dan faktor pendapatan sebagaimana telah dijelaskan di atas.Demikian halnya dalam penelitian disertasi ini, dari hasil perhitungan diketahui bahwa harga pangan beras berasosiai positif kepada ketersediaan pangan rumah tangga di daerah penelitian. Ketersediaan pangan rumah tangga diperoleh dari berapa besar alokasi pendapatan rumah tangga yang digunakan untuk mengkonsumsi pangan beras sebagai nilai proxy untuk 
menentukan besar kecilnya ketersediaan pangan rumah tangga di daerah penelitian. Ketika harga bahan pangan beras naik atau bertambah maka ketersediaan pangan di daerah penelitian cendrung naik atau bertambah berbanding sejajar. Kondisi tersebut tidak sesuai dengan harapan teoritis yang sesungguhnya mengatakan bahwa setiap kenaikan harga pangan beras, seharusnya diikuti dengan berkurangnya konsumsi beras oleh rumah tangga responden.

Akan tetapi hasil penelitian ini menunjukan fenomena yang lain yaitu kenaikan harga beras diikuti dengan semakin bertambahnya ketersediaan panganrumah tangga responden. Logika berpikir yang mendasari fenomena tersebut adalah ketika harga pangan beras naik, maka rumah tangga responden tetap akan mengkonsumsi bahan pangan beras tetapi dengan kuantifikasi yang lebih sedikit. Logika berpikir yang kedua adalah kenaikan harga beras maka rumah tangga responden juga dapat mempertahankan konsumsi pangan beras dalam jumlah yang sama untuk tetap menjaga ketersediaan pangan rumah tangga. Hal ini disebabkan tingkat pendapatan yang diperoleh masih mampu untuk memberikan ruang bagi rumah tangga responden individual untuk melakukan konsumsi atau rumah tangga rumah tangga responden akan melakukan pengalihan jumlah alokasi pendapatan yang digunakan untuk konsumsi pangan beras dalam rangka menjaga ketersediaan pangan rumah tangga responden dalam satu bulan.Secara teori ekonomi maka dalam hukum permintaan dikatakan bahwa jika harga suatu produk naik maka jumlah barang yang dikonsumsi akan cendrung berkurang (citeris paribus). Akan tetapi fakta di lapangan menunjukan situasi yang berbeda yaitu terjadi penyimpangan perilaku rumah tangga responden dalam melakukan kegiatan konsumsi. Hal ini menurut pendapat peneliti sebagai suatu bentuk paradoksal yang terjadi di Maluku, hal inipun sesuai dengan temuan Sir Roberth Given di Irlandia Utara yang di dalam teori ekonomi mikro disebut paradox Given.

\section{KESIMPULAN / CONCLUSION}

Harga beras berpengaruh signifikan terhadap ketersediaan pangan rumah tangga di Provinsi Maluku. Besarnya pengaruh Harga beras terhadap ketersediaan pangan rumah tangga adalah $82,4 \%$. Hal ini menunjukkan bahwa pengaruh harga beras terhadap ketersediaan pangan sangat besar dibandingkan faktor lain yang belum dijelaskan dalam penelitian ini. Hasil penelitian ini menunjukkan bahwa dengan peningkatan harga beras di pasar maka ketersediaan harga pangan pada rumah tangga juga tetap meningkat. Hal ini dapat menunjukkan bahwa jika harga beras naik, maka dapat disibtitusi dengan 
William G. M. Louhenapessy, Beras Sebagai Barang Subtitusi dan Komoditi Pangan Utama.

ketersediaan pangan lain selain beras. Oleh karena itu, untuk terus meningkatkan ketersediaan pangan rumah tangga di Provinsi Maluku maka Pemerintah Provinsi Maluku dapat melakukan kebijakan terkait dengan harga beras dan pangan subtitusi untuk beras.

\section{DAFTAR PUSTAKA / REFERENCES}

Alimoeso, Sutarto. Menuju Lumbung Pangan Dunia. Jakarta : Gibon Books, 2009

Engel, J.F., R.D. Blackwell, dan P.W. Miniard., 1994. Perilaku Konsumen. Penerbit Binarupa Aksara, Jakarta.

Girsang, Wardis., 2014. Socio-Economic Fakctors That Have Influenced the Decline of Sago Consumption in Small Island : A Case in Rural Maluku, Indonesia. Reaserch Center For The Pacific Islands. Kagoshima University, Japan.

Hafsah, Jafar, 2006. Pertanian dan Pangan. Revitalisasi Pertanian dan Dialog Perdebatan. Penerbit Buku. Kompas, Jakarta.

Hetharia, M.E., 2006. Kembali Makan Sagu (Masalah dan Tantangan). Prosiding Sagu dalam Revitalisasi Pertanian Maluku. Ambon, 29-31 Mei 2006. Kerjasama Pemerintah Propinsi Maluku dengan Fakultas Pertanian, Universitas Pattimura. Badan Penerbit Fakultas Pertanian Universitas Pattimura, Hal. 52-59.

Kurnia, R. S., Agustono, Rahayu, W. 2008. Analisis Peran Lumbung Desa Terhadap Ketersediaan Pangan Pokok Rumah Tangga Petani. SEPA. Vol. 4. No. 2. Februari 2008. Hal. 103-112.

Louhenapessy J.E. dkk, 2010. Sagu Harapan dan Tantangan. Penerbit PT. Bumi Aksara, Jakarta.

Maxwell, S., and Frankenberger, T. (1992). Household Food Security Concepts, Indicators and Measurements. New York, ny. USA : Unicef and Ifad.

Nainggolan, K. 2004. Strategi dan Kebijakan Pangan Tradisional dalam Rangka Ketahanan Pangan. Seminar Nasional Peningkatan Daya Saing Pangan Tradisional. Balai Penelitian dan Pengembangan Pascapanen Pertanian Bogor.

Pakpahan, A., H.P. Saliem, S.H. Suhartini dan N. Syafa'at. 1993. Ketahanan Masyarakat Berpendapatan Rendah. Monograph Series No. 14. Pusat Penelitian dan Pengembangan Sosial Ekonomi Pertanian. Bogor.

Saliem, H.P., M. Ariani, Y. Marisa dan T. B. Purwantini. 2002. Analisis Kerawanan Pangan Wilayah Dalam Perspektif Desentralisasi Pembangunan. Laporan Hasil Penelitian Pusat Penelitian dan Pengembangan Sosial Ekonomi Pertanian. Bogor.

Subejo. 2009. Perangkap Malthus : Pertarungan Ledakan Penduduk dan Pangan, The University of Tokyo Departement of Agricultural and Resource Economic. 
Tambunan, 2008. Ketahanan Pangan di Indonesia. Mengidentifikasi Beberapa Penyebab. Pentingnya Ketahanan Pangan. Pusat Studi Industri dan UKM Universitas Trisakti.

Yamamoto, S. 2013. Food Security on Chuuk Atoll, Federated States of Micronesia Proceeding of the Ninth International Small Island Conference (Tual and Langgur, Maluku, Indonesia). 